UDC 618.36-008.64-02:618.15-022.7]-07-08

DOI:10.24061/2413-0737/XXI.2.82.2.2017.74

\title{
S.M. Yasnikovska, H.T.Hrytsak \\ DIAGNOSTIC FEATURES OF PLACENTAL DYSFUNCTION IN PREGNANT WOMEN WITH BACTERIAL VAGINOSIS
}

Higher State Educational Institution of Ukraine «Bukovinian State Medical University» (Chemivtsi)

\begin{abstract}
The article presents doppler ultrasound test results of uterine arteries resistance in women with bacterial vaginosis in early term of gestation. When the systolicdiastolic relation in uterine arteries is more than 2,9 , the resistance index is more than 0,46 and the pulsating index is more than 1,82 , the formation of primary placental dysfunction is diagnosed. Early pathogenetically substantiated
\end{abstract}

Introduction. Placental dysfunction (PD) is a multicomponent syndrome resulting from the violation of compensatory-adaptive mechanisms of fetoplacental complex (FPC) and takes a leading place in the structure of perinatal pathology and mortality. It is proved by numerous investigations that infection is one of the main reasons that leads to the formation of PD and defines health condition of newborns. This is largely due to the tropism of pathogens towards embryonic tissue, and also because the fetal cells with their high metabolism is the perfect breeding ground for organisms [1]. In patients with acute exacerbation of infectious diseases during pregnancy, 55,2 \% is PD ones. There are also data that $\mathrm{PD}$ in women with vaginal microcenosis disorders are observed by 2-4 times more often than in healthy pregnant women [8].

A variety of clinical manifestations of PD, frequency, nature and severity of complications for mother and fetus, the prevailing disorders of one or another function of the placenta depends on the gestation period, extent, duration and the nature of the damaging factors, as well as the stage of development of the fetus and placenta. Scientists have proved that the development of the placental and insufficiency and that of the placental bed occur in very early stages, up to 16 weeks with extragenital diseases and up to 12 weeks with the threat of abortion, particularly with concomitant somatic pathology $[2,7]$.

Normal pregnancy course, fetal growth and development depends on the blood flow in the mother-placenta-fetus, the violation of which determines the pathogenesis of many complications of pregnancy, including PD. Currently, one of the promising methods for assessment of uterineplacental hemodynamics is an ultrasound investigation based on the doppler effect. The high information content, noninvesivness, relative simplicity, safety and the possibility of use during pregnancy make this method of investigation the best one.

Quick and efficient obtaining of doppler spectrum of curves velocity bloodstream in uterine arteries (UA) is achieved by using color mapping mode, which allows you to determine the level of branching vessels till the spiral arteries. For quantitative assessment of doppler velocity spectrum in bloodstream correction of revealed violations allowed to reduce the risk of placental dysfunction in this group of pregnant women in 3,9 times and fetal growth retardation (FGR) by 7,9 times compared to the average population data.

Key words: placental dysfunction, bacterial vaginosis, doppler ultrasound of the uterine arteries.

angleindepended indicators are used - resistance index (RI), pulsation index (PI) and the ratio of the maximum systolic and end diastolic velocity (S/D). The value of PI is independent of the maximum systolic and end diastolic velocity, and therefore better reflects qualitative changes of blood flow in UA [4].

The conducted studies indicate the need to obtain the spectrum of curves velocity bloodstream in both uterine arteries (UA), as impaired blood flow in the UA is more than $70 \%$ of cases are detected only on one side [5]. Sustainability of the utero-placental blood flow in the pregnancy progression is ensured by reducing the preplacental resistance of the blood flow during the trophoblast invasion into the spiral arteries, as the replacement of muscular and elastic membranes by fibrinoid occurs and clearance of vessels expands. Dynamic change of the doppler spectrum quality during the first trimester of pregnancy can be observed. If normally it is characterized by a shallow cavity in early diastole, then with the beginning and the progression of pregnancy the cavity gradually disappears and the RI reduces. The maximum decrease in UA resistance eventuates till 16 weeks, due to the completion of the morphological changes of spiral arteries and final formation of low resistant blood flow in the UA basin [6].

Molecular mechanisms of adaptation and homeostatic reactions in the placental bed of the uterus and placenta differ both in nature and in time identified violations, including apoptosis, the state of cell membranes and protein biosynthesis. The ineffectiveness of antenatal treatment of fetoplacental disorders, such as in the period of 16-18 weeks due to the fact that in this period of gestation the formation of placental bed of the uterus is completed in the conditions of angiopathy, including uterine vessels, leading to its initial failure, and accordingly to placental dysfunction with all its complications [7].

The ineffectiveness of antenatal drug therapy, carried out in the second and third trimesters of pregnancy, is likely due to the fact that intra trouble begins at the stage of the microenvironment of human embryo (extraembryonic structures) that forstall in its development the embryo and fetus, which subsequently leads to inferior structure and fetoplacental functioning in general [2]. Therefore, prompt and 
accurate diagnosis of PD is the key to success in the treatment of this category of women. In addition, most researches on the issue of ineffectiveness of antenatal care, originate from the study of the state of formed placenta.

Purpose of the research. To study the significance of doppler investigation in the diagnosis of placental dysfunction in pregnant women with bacterial vaginosis in early gestation.

Material and methods. 90 pregnant women at the term gestation of 8-12 weeks were examined in obstetric clinic. The average age of patients was $27,3 \pm 1,4$ years. All surveyed were divided into two groups: the first group (basic) amounted 50 pregnant women with bacterial vaginosis $(\mathrm{BV})$, the second group (control) - 40 pregnant women with normal vaginal microflora.

The analysis of the initial clinical characteristics, pregnancy course peculiarities and childbirth, obstetrical and gynecological research was made. During the age study, medical history and physical health and social characteristics of women's groups compared significant difference wasn't found.

We used bacterioscopic, bacteriological, ultrasonic methods, polymerase chain reaction, $\mathrm{pH}$ vaginal discharge.

Utero-placental circulation research was performed on the ultrasound diagnostic device "SonoAce 8000 Life". Herewith color doppler flow mapping and pulsed doppler of the uterine arteries were performed. Assessment of curves flow velocities was performed by determining the systolicdiastolic ratio (S/D), resistance index (RI) and pulsating index (PI). S/D is a reatio of maximum systolic and end diastolic velocity circulation $(S / D=A$ / $\mathrm{D}), \mathrm{PI}$ is expressed by the ratio in the difference between maximum systolic and end diastolic velocity to average circulation velocity $(\mathrm{PI}=\mathrm{A}-\mathrm{D} / \mathrm{M}), \mathrm{RI}$ is determined by the ratio of the difference between maximum systolic and end diastolic velocities to maximum systolic velocity of circulation (IP $=\mathrm{A}-\mathrm{D}$ / A), where $\mathrm{A}$ is a maximum systolic blood flow velocity, D - end diastolic velocity.

Statistical analysis of research results was carried out with the implementation of modern methods of variation statistics using standard statistical analysis of Microsoft Excel 5,0 software.

At 30 weeks of gestation all patients of primary comparison group were examined for diagnosis of placental dysfunction (if the primary placental insufficiency that was evolving, progressed to placental dysfunction).

Results and discussion. Screening diagnosis criteria of BV were: a large or moderate amounts of homogeneous vaginal milk colored discharges with an unpleasant sharp smell; Vaginal $\mathrm{pH}$ content $\geq 4,5$; positive amine test; "key" cells in the smears of vaginal discharge stained by Gram.

Women with $\mathrm{BV}$ vaginal $\mathrm{pH}$ content was in the range of 4,5 to 7,2 (the average $5,8 \pm 0,09$ ). In the patients with normal vaginal microflora $\mathrm{pH}$ measuring vaginal discharge were within 3,5-4,4 (average
$4,3 \pm 0,01)$. Amine test was positive in all women in the main study group.

The results of microbiological studies found a massive settlement of vaginal microbial habitat in the main group of women. In addition to that lactobacilli were absent in 88,0\% (as we know, the recent are the indicators of the health of the ecological environment in the vagina). More frequently are distinguished coagulase negative staphylococci $(56,0 \%$ in number of 103-108 CFU / mL), non-pathogenic rootbacteria $\left(18,0 \%\right.$ in the number of $10^{3}-104 \mathrm{CFU} /$ $\mathrm{ml})$, colibacillus $\left(12,0 \%\right.$ in the number of $10^{3}-104$ $\mathrm{CFU} / \mathrm{ml}$ ). When comparing the microbial landscape of women in the second group of lactobacilli found in sufficiently high titer - 105-109 CFU / ml. The important note here is the presence of proteus bacteria in the vagina of women in the first group $(8,0 \%$ 103-104 CFU / mL), Klebsiella (4,0 \% - 103 CFU / $\mathrm{ml})$ and yeast fungi genus Candida (54,0\% - 103$106 \mathrm{CFU} / \mathrm{ml}$ ).

The range of optional - anaerobic microorganisms was high. Unlike patients with normal flora, patients with BV had no optional but anaerobic lactobacilli that are not able to produce hydrogen peroxide, which inhibits the growth of pathogens through the direct toxic effect on them. Thus, the study which was carried out showed that screening tests - diagnostic BV often coincide with the results of classic microbiological diagnostics.

Doppler research indexes flow in the uterine arteries showed a significant increase in vascular resistance index in 23 (46\%) of the main group of pregnant being observed. Thus, the rate of vascular resistance in the uterine arteries were higher normative values on average 1,5-2 times (C / D - 2,9 10,45 ;

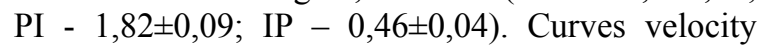
flow in the uterine arteries are characterized by low diastolic component. In $11 \%$ of cases in doppler investigation an abnormal slot in diastole phase was found.

In the uterine artery pool in the control group low resistant blood flow was observed. Curves velocity of the blood flow in the uterine arteries are characterized by low pulsation and high diastolic component. Average indexes values of vascular resistance S/D, PI and RI in the uterine arteries were correspondingly $1,91 \pm 0,6 ; 0,58 \pm 0,04 ; \quad 0,33 \pm 0,08$, which corresponded to limits allowable for a given gestational age.

Pregnant women of the core group with impaired utero-placental circulation were given the diagnosis of primary placental dysfunction, which is being formed. Relevant pathogenetic therapy according to the clinical protocols by Ministry of Health of Ukraine has been correspondingly administered. Hereafter in the 30 weeks of gestation diagnosis of placental dysfunction occurred in $4(17,4 \%)$ of 23 patients examined, and fetal growth retardation (FGR) found in $1(4,3 \%)$ pregnant women from this group after treatment. 


\section{Conclusions}

Significant changes in doppler investigation indexes of blood flow in the uterine arteries of examined pregnant women with bacterial vaginosiswere observed as the result of the conducted research. The diagnostic criteria revealed placental bed insufficiency, and at the preclinical stage allowed to diagnose PPD (at 8-12 weeks gestation). Early pathogenetically substantiated correction of violations, allowed to reduce the risk of placental dysfunction and fetal growth retardation in women with bacterial vaginosis compared with the average population data.

Perspective of further investigations. Deep study of changes in utero-placental blood flow in women with bacterial vaginosis in the first trimester and correction of its infringements will have practical significance for the development of comprehensive treatment of placental dysfunction to the clinical stage in this group of pregnant women and prevention of perinatal complications.

\section{References}

1. Бубнова Н.И. Репродуктивные потери при декомпенсированной плацентарной недостаточности, вызванной инфекцией / Н.И. Бубнова, В.Л. Тютюнник // Акуш. и гинекол. - 2010. - № 4. - С. 44-48.
2. Краснопольский В.И. Формирование и патология плаценты / Краснопольский В.И. - М.: Медицина, 2007. $-112 \mathrm{c}$.

3. Магаева Ф.Ю. Эффективность эхографии и допплерометрии в диагностике плацентарной недостаточности у беременных с бактериальным вагинозом / Ф.Ю. Магаева, Л.В. Майсурадзе // Кубанск. науч. мед. вест ник. - 2015. - № 3 (152). - С. 72-77.

4. Медведев М.В. Настало время перехода с ИР на ПИ при оценке кровотока в маточних артериях во время беременности / М.В. Медведев, А.Ю. Блинов // Пренат. диагност. - 2016. - Т. 15, № 1. - С. 48-51.

5. Медведев М.В. К вопросу о более широком применении оценки кривых скоростей кровотока в маточных артериях в 11-14 недель беременности для выделения группы высокого риска по преэклампсии и задержке роста плода / М.В. Медведев, П.В. Князев // Пренат. диагност. - 2015. - Т. 14 (1). - С. 24-26.

6. Милованов А.П. Цитотрофобластическая инвазия ключевой механизм развития нормальной и осложненной беременности / А.П. Милованов, А.К. Кириченко. - Красноярск: Литера-принт, 2009. - 188 с.

7. Радзинский В.Е. Ранние сроки беременности / В.Е. Радзинский, А.А. Оразмурадова. - М.: Status Praesens, 2008. $-448 \mathrm{c}$.

8. Серов В.Н. Современные представления о бактериальном вагинозе / В.Н. Серов, А.Л. Тихомиров, Ч.Г. Олейник // Вопр. гинекол., акуш. и перинатол. 2005. - T. 4, № 1. - C. 66-71.

\section{ОСОБЕННОСТИ ДИАГНОСТИКИ ФОРМИРУЮЩЕЙСЯ ПЛАЦЕНТАРНОЙ ДИСФУНКЦИИ У БЕРЕМЕННЫХ С БАКТЕРИАЛЬНЫМ ВАГИНОЗОМ}

\section{С.М. Ясниковская, А.Т. Грицак}

Резюме. В статье наведены результаты допплерометрического исследования резистентности маточных артерий у женщин с бактериальным вагинозом на ранних сроках гестации. При значении в маточных артериях систолодиастолического соотношения больше 2,9 , индекса резистентности больше 0,46 и пульсационного индекса больше 1,82 выставлен диагноз формирующейся первичной плацентарной дисфункции. Ранняя, патогенетически обоснованная коррекция выявленных нарушений разрешила снизить риск развития плацентарной дисфункции у данного контингента беременных в 3,9 раза и задержку внутриутробного развития плода в 7,9 раза по сравнению со среднепопуляционными данными.

Ключевые слова: плацентарная дисфункция, бактериальный вагиноз, допплерометрия маточных артерий.

\section{ОСОБЛИВОСТІ ДІАГНОСТИКИ ПЛАЦЕНТАРНОЇ ДИСФУНКЦІЇ, ЩО ФОРМУСТЬСЯ У ВАГІТНИХ ІЗ БАКТЕРІАЛЬНИМ ВАГІНОЗОМ}

\section{С.М. Ясніковська, Г.Т. Грицак}

Резюме. У статті представлено результати доплерометричного дослідження резистентності маткових артерій у жінок із бактеріальним вагінозом у ранні терміни гестації. При значенні в маткових артеріях систолодіастолічного відношення більше 2,9, індексу резистентності більше 0,46 та пульсаційного індексу більше 1,82 діагностовано первинну плацентарну дисфункцію, що формується. Рання, патогенетично обгрунтована корекція виявлених порушень дозволила знизити ризик розвитку плацентарної дисфункції в даного контингенту вагітних у 3,9 раза та затримку внутрішньоутробного розвитку плода в 7,9 раза порівняно із середньопопуляційними даними.

Ключові слова: плацентарна дисфункція, бактеріальний вагіноз, доплерометрія маткових артерій.

Вищий державний навчальний заклад України «Буковинський державний медичний університет (м. Чернівці)

Рецензент - проф. О.С. Хухліна

Buk. Med. Herald. - 2017. - Vol. 21, № 2 (82), part 2. - P. 127-129

Надійшла до редакції 17.09.2017 року

(C) S.M. Yasnikovska, H.T.Hrytsak, 2017 